\title{
THE SELECTED ASPECTS OF TOURISM DEVELOPMENT - AN EXAMPLE OF THE ŚWIĘTOKRZYSKIE PROVINCE
}

\author{
IWONA KINIORSKA
}

The Jan Kochanowski University in Kielce, POLAND

e-mail: iwona.kiniorska@ujk.kielce.pl

KEYWORDS | demographic potential, economic potential, infrastructure

ABSTRACT $\quad$ Tourism belongs in to the most important elements of multifunctional development of rural areas. The main goal of this study is to assess conditions for tourism development with special emphasis on demographic, economic and infrastructural processes. The study has been based on the data from the Local Data Bank of the Central Statistical Office of Poland and focused on the period of 2002-2012. The area of the study the rural areas of the Świętokrzyskie Province.

\section{Introduction}

Tourism is commonly considered a phenomenon of the 20th and 21st century. In both highly developed and developing countries it is associated with the strong influence on the income of 
a country and improvement of economic conditions on regional and local levels. ${ }^{1}$ Presently, the percentage of agricultural production in the economy of rural areas is decreasing, overridden by non-agricultural production and consumption, e.g. sharing natural environment (tourist and recreation services). ${ }^{2}$ Tourism is an excellent tool stimulating economic growth and social development. It is also considered to be an interdisciplinary branch of economy with multi-sector relations. The importance of tourism for generating regional influences and employment is all the more visible as employment opportunities in agriculture are decreasing. ${ }^{3}$

The goal of this study is to assess the selected socio-economic aspects affecting tourist function development in the rural areas of the Świętokrzyskie Province. The author analyses 97 communes covering the area of $11,042 \mathrm{~km}^{2}$ with the population (in 2013) of 700,445 inhabitants, which amounted to $94 \%$ of this province's area and $55.20 \%$ of the entire province's population. The study is based on the statistical data of the Central Statistical Office of Poland for the period of 2002-2012. Despite the imperfections of the statistical data on tourism as provided by the Central Statistical Office of Poland, its comprehensiveness as a source of information on the tourist traffic and accommodation in Poland is an advantage. The study applies the analyses of indices including tourist accommodation density index (number of bed places in tourist accommodation per $1 \mathrm{~km}^{2}$ of the total area), the Defert index - tourist function index (number of tourists accommodated per $1 \mathrm{~km}^{2}$ of the total area) and the Schneider index - tourist traffic intensity index (number of tourists accommodated per 1,000 permanent residents). The indices are commonly used in the studies on tourist function. They have been used by such authors as Warszyńska [1985], Chudy-Hyski [2006], Żek [2008], Szromek [2012]. The Perkal index has been used as a synthetic measure for identifying the tourist function and differentiation of demographic and economic potential.

Studies on the relations between tourist function and socio-economic development have been more intense from the 1970s on. From that time on numerous concepts and academic analyses of the subject appeared in the literature on the subject. In Poland the impact of tourism on selected aspects concerning socio-economic level has been discussed, among others, by A. Jackowski (1981). Regarding the latest studies, the one by R. Faracik (2006) is worth mentioning; he developed the spatial typology of communes from the Krakow suburban zone according to the structure of the tourist function. D. Chudy-Hyski (2006) examine the relation between the level of tourist function development of an area and the effectively operating - within its administrative borders - legally protected areas. A. Szwichtenberg (2006) describes the significance of tourist function of seaside communes in Poland with respect to other economic functions. Possible ways of the tourist function development have been discussed in the studies by B. Górz (2007). The subject

${ }^{1}$ A. Tucki, Regionalne aspekty rozwoju turystyki na przykładzie województwa lubelskiego, in: Studia nad turystyka. Prace geograficzne i regionalne, Geograficzne, społeczne i ekonomiczne aspekty turystyki, Instytut Geografii i Gospodarki Przestrzennej, Uniwersytet Jagielloński 2007, p. 267.

${ }^{2}$ M. Kłodziński, Główne funkcje polskich obszarów wiejskich z uwzględnieniem dezagraryzacji wsi i pozarolniczej działalności gospodarczej, „Studia BAS” 2010, No. 4 (24), p. 9.

${ }^{3}$ Majewska I., Kierunki rozwoju turystyki na obszarach wiejskich $w$ nowej perspektywie finansowej Unii Europejskiej, in: Turystyka wiejska bez granic, ed. C. Jastrzębski, Wyższa Szkoła Ekonomii, Praw i Nauk Medycznych w Kielcach, 2015, p. 39. 
of analysis of tourist function development is continued by such authors as A.R. Szromek (2012) and M. Durydiwka (2007, 2012).

Owing both to the changes in the 1990s economy and dynamic growth of service sector, studies on the innovation in services, including tourism, have become more important. In Poland, after the transformation and the introduction of free market economy, the subject of innovative concepts of agritourism management has been covered - among others - by M. Woźniak (2010). He claims that the market success of agritourism farms not only depends on product elements but is mostly affected by the features that make a particular farm easily accessible and unique. It requires a new approach to management and innovation. Innovations in tourism is also discussed by K. Krzyżanowska (2013). The question of innovation in rural area tourism has also been described by A.J. Parzonko (2013), with the presentation of the agricultural advisory.

The subject of agritourism has been popular and analysed for many years. In the Swietokrzyskie Province the group of authors who have discussed it includes I. Janowski (2004), E. Pałka (2007), W. Kamińska, M. Mularczyk (2010), W. Kamińska, E. Pałka-Łebek (2009), W. Kamińska, Piwońska E. (2009), I. Kiniorska, J. Wrońska-Kiczor (2010), D. Puciato, B. Woś (2011).

\section{Area of the study}

The Świętokrzyskie Province comprises an Eastern Poland area which, due to its peripheral character, has to face numerous negative social and economic phenomena. The majority of the area in question coincides with the Świętokrzyski National Park and Landscape Parks of the Świętokrzyskie Mountains. The legal restrictions concerning locations for infrastructural investments on legally protected areas are sources of conflicts between park officers, ecologists and investors. The place of infrastructural investments influences living conditions and transforms the natural environments, not necessarily in a positive way. The area of the Świętokrzyskie Province is functionally diversified. Apart from agricultural function, another important element is economic activity connected with the concentration of extractive industry (mining) and raw materials processing, including limestone for cement and lime industries. It is represented by huge - on the national level - companies, i.e. „Morawica” Limestone Quarry (Kopalnia Wapienia „Morawica”), Dyckerhoff Cement Plant and „Trzuskawica” Limestone Processing Company (Zakłady Przemysłu Wapienniczego „Trzuskawica”, Sitkówka-Nowiny).

One of the most characteristic places of the environmental transformation associated with raw materials extraction is the Sitkówka-Nowiny commune. Its western part is a fragment of the Chęciny-Kielce Landscape Park where agricultural and natural landscapes prevail. In the central and eastern parts where the increasing volumes of carbonate raw materials are extracted for construction industry, industrial landscape is the dominant type. The most interesting area with respect to geology and extraction of raw materials is the surrounding area of Kowala (the eastern part of the commune) where two landscape types can be distinguished. The first one is the extractionrelated (mining) landscape associated with the current extractive activities in numerous existing companies (mine workings, mine-waste tips, overburden removings, haul roads). The second one 
is the post-extraction (post-mining) landscape, ${ }^{4}$ where the extraction of raw materials has been finished (old excavation voids and waste-dumps). As the literature on the subject shows, the Świętokrzyskie Province is not counted as a major tourist region in Poland. However, its tourist function can be developed in some of its parts, either as the dominant or an additional function. In order to encourage tourists to visit certain places, tourist attractions - natural environment, landscape and cultural - are necessary. Afforestation is a major attraction of the area in question the Świętokrzyski National Park (Świętokrzyski Park Narodowy). In the Świętokrzyskie Province there are numerous iron smelting facilities from the Roman period. Industrial tourism encourages learning and education and can play a key role in cultural education.

\section{Socio-economic conditions}

Tourism and leisure activities can be of basic, supplementary or marginal importance to the economic development of the said area. Its role in a local economy is defined not only by tourist values and the development of tourist facilities and tourist traffic but also social and economic potential. The impact of human factor on the development of rural and urban areas is beyond question. It is expressed by the demographic potential and economic activity of a given region. In the period of 2002-2012 the population of rural areas dropped 0.5 per cent to 701.8 thousand inhabitants from 702.8 thousand. The most significant changes in population (fall) have been recorded in the southwestern part of the province. However, rural areas located mainly in the vicinity of the province's capital city grew in population (e.g. Morawica, Miedziana Góra, Sitkówka-Nowiny). ${ }^{5}$

By means of applying the Perkal synthetic index, areas of diversified demographic potential have been recognised in the Świętokrzyskie Provinces. The highest class is composed of two communes: Morawica and Miedziana Góra. The high demographic potential is the feature of the communes located in the vicinity of the province's capital city (positive migration rate). It is also visible in rural areas surrounding subregional centres: Busko Zdrój, Połaniec. Unfavourable demographic conditions have been recorded in the southern and southwestern parts of the province - the areas of advanced depopulation. These areas are associated with traditional agriculture and have peripheral location to urban centres. The concentration of demographic potential on relatively small areas causes a development imbalance between rural areas. The decreasing population, due to the negative migration rate, is correlated with the negative rate of natural increase and unfavourable age structure of the population remaining in its place of residence, because migrations are selective and refer to younger and better educated parts of the population, which negatively affects entrepreneurship, innovations as well as the social activity of persons not leaving their

${ }^{4}$ J. Nita, Kamieniołom $w$ krajobrazie i geoturystyce, in: Krajobraz a turystyka, ed. Andrejczuk, Prace Komisji Krajobrazu Kulturowego PTG, nr 14, Sosnowiec 2010, pp. 243-51.

${ }^{5}$ I. Kiniorska, Potencjał rozwojowy obszarów wiejskich woj. świętokrzyskiego a polityka spójności, ,Studia KPZK PAN" 2014, t. CLVI, p. 360. 
place of residence. ${ }^{6}$ Migration studies have for long shown that one of its features is the fact that migrating persons leave areas with unfavourable conditions in order to satisfy such needs as having interesting and well-paid jobs, access to public services, better housing conditions, etc. Therefore, migrations from more distant rural locations to suburban zones are classic spatial movements described by migration models using the analysis of attracting (pull) and discouraging (push) factors. Migrations from urban to suburban zones are also typical to populations with increasing wealth and those searching for better living conditions - dwellings located far from noise and pollutions, with more space, with a garden, etc.?
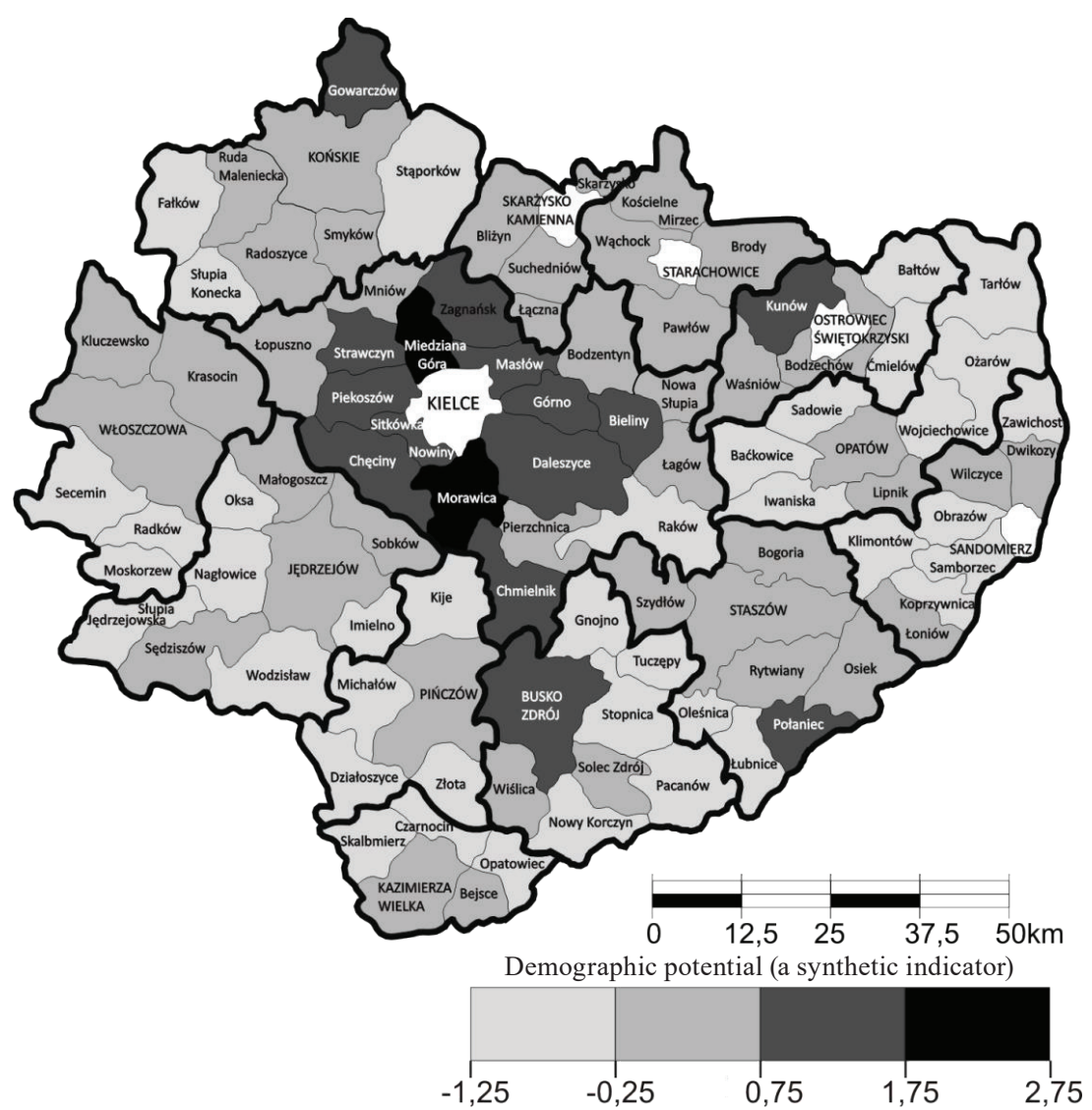

Figure 1. Demographic potential of rural areas of the Świętokrzyskie Province in 2012 Source: the author's own calculations based on data from the Central Statistical Office of Poland.

${ }^{6}$ A. Miszczuk, Kapitat ludzki i społeczny w procesie rozwoju obszarów wiejskich woj. lubelskiego, „Studia KPZK” 2010, t. CXXVI, p. 152.

${ }^{7}$ A. Rosner, Zróżnicowanie przestrzenne obszarów wiejskich a pożądane kierunki ich rozwoju, „Studia KPZK” 2011, t. CXXXIII, p. 40. 
In the transformation period rural areas differ in adaptation levels for market economy and new social and political conditions. Differentiation of development potential and the utilisation rate of advantages of a particular area have a huge impact on the demographic, spatial and functional structure of rural areas (Kiniorska 2009: 31).

The analysis of the economic potential has shown important spatial diversities. It took into account such features as the unemployment rate, entrepreneurship rate, income per capita, percentage of persons using sewage and water supply system. The economic potential has been observed in relatively small areas (Figure 2).

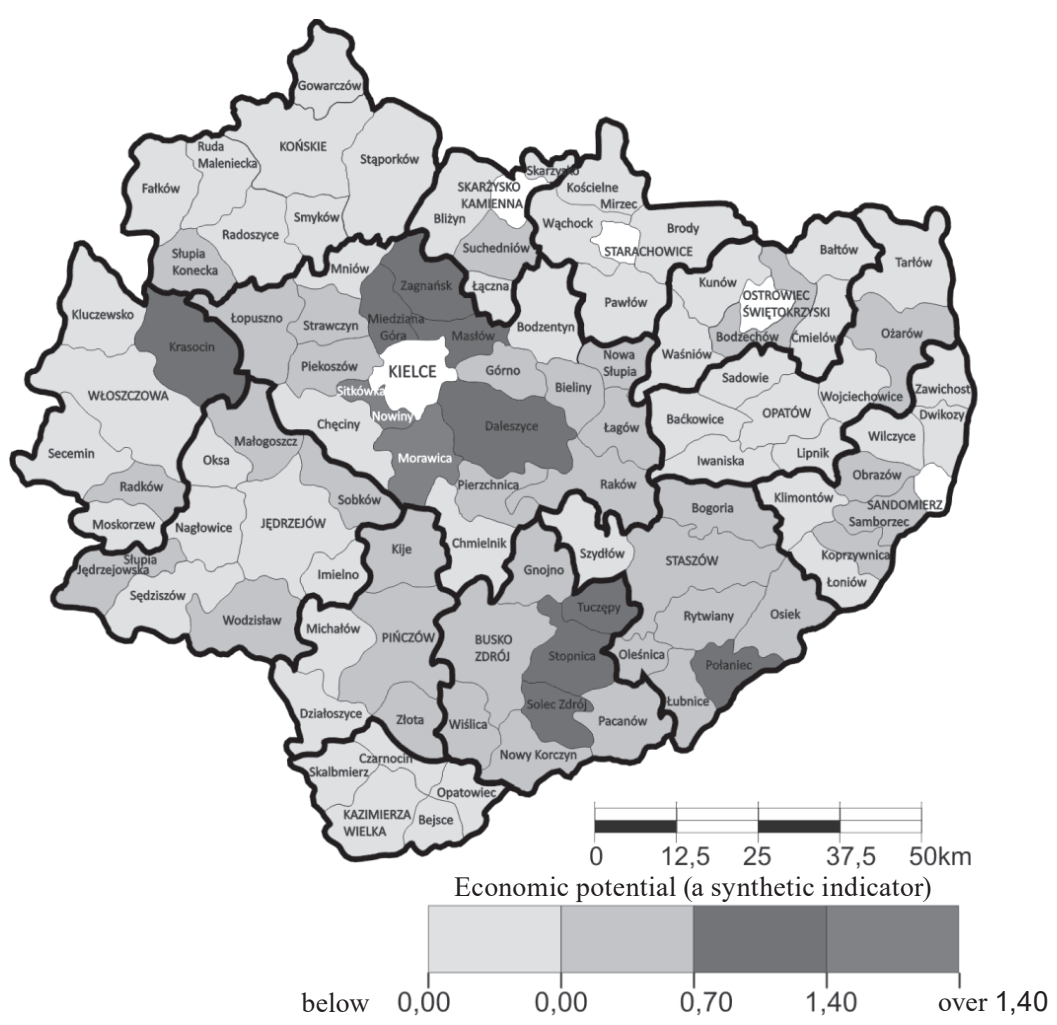

Figure 2. Economic potential of rural areas of the świętokrzyskie Province in 2012

Source: author's own calculations based on data from the Central Statistical Office of Poland.

These are rural areas with specialised industrial or services functions. The concentration of socio-economic potential on a relatively small area leads to the extended inequalities in development. Functional structure of the area and its character (the Świętokrzyskie Mountains $67 \%$ of their area with the legally protected natural values) affect the investments and development including tourism. 


\section{Diversification of tourist function in rural areas}

Currently, the socio-economic development of rural areas is a broad category including not only the diversification of rural economy (i.e. simultaneous economic functions of rural areas targeting and achieving multi-functionality of rural areas), economic activation of rural population connected with stimulating local entrepreneurship and attracting external investments, but also improving living conditions and the quality achieved by maintaining natural and cultural values. ${ }^{8}$ Numerous rural areas of the Świętokrzyskie Province have not developed fully their tourist function despite their natural and cultural values. It is confirmed by calculations and tourist development indices. In 2002 the accommodation was concentrated in 34 villages. At the time, the highest tourist accommodation density index was recorded in Końskie, Masłów and Górno (Table 1). For the Defert- and the Sneider indices similar tendencies were observed then. The highest values were recorded in three communes: Bodzentyn, Masłów and Górno.

Table 1. Indicators describing tourist phenomena in rural areas of the Świętokrzyskie Province in 2002

\begin{tabular}{|c|c|c|c|}
\hline Territorial unit & $\begin{array}{c}\text { Tourist } \\
\text { accommodation } \\
\text { density index }\end{array}$ & Defert's index & Schneider's index \\
\hline 1 & 2 & 3 & 4 \\
\hline Bodzechów & 0.33 & 4.09 & 37.15 \\
\hline Bodzentyn - rural area & 3.56 & 178.35 & $2,859.00$ \\
\hline Brody & 0.17 & 7.77 & 115.06 \\
\hline Busko-Zdrój-rural area & 0.55 & 12.12 & 179.91 \\
\hline Chęciny - rural area & 0.13 & 1.22 & 13.36 \\
\hline Chmielnik - rural area & 0.04 & 0.15 & 2.66 \\
\hline Daleszyce & 0.87 & 9.62 & 149.75 \\
\hline Górno & 5.53 & 333.10 & $2,214.42$ \\
\hline Klimontów & 0.04 & 0.66 & 7.45 \\
\hline Kluczewsko & 0.06 & 0.29 & 7.60 \\
\hline Końskie - rural area & 6.65 & 88.31 & $1,318.64$ \\
\hline Łagów & 0.51 & 14.27 & 228.36 \\
\hline Łączna & 1.94 & 76.73 & 910.95 \\
\hline Łopuszno & 0.34 & 3.02 & 59.79 \\
\hline Małogoszcz - rural area & 1.47 & 40.74 & 713.00 \\
\hline Masłów & 5.60 & 259.56 & $2,430.27$ \\
\hline Michałów & 0.54 & 0.45 & 10.08 \\
\hline Miedziana Góra & 4.93 & 89.68 & 676.69 \\
\hline Nagłowice & 1.85 & 17.71 & 382.99 \\
\hline Nowa Słupia & 1.74 & 80.10 & 701.38 \\
\hline Opatowiec & 0.29 & 21.22 & 388.84 \\
\hline Pawłów & 0.18 & 2.04 & 18.69 \\
\hline Pińczów - rural area & 0.25 & 32.18 & 616.90 \\
\hline Raków & 0.26 & 0.94 & 29.82 \\
\hline
\end{tabular}

${ }^{8}$ K. Heffner, Kierunki zmian w przestrzeni wiejskiej Polski-wpisywanie się w przestrzeń wsi europejskiej, ,,Studia KPZK"2014, Vol. CLVI, p. 37. 


\begin{tabular}{lcrr}
\hline & 1 & 3 & \multicolumn{1}{c}{4} \\
\hline Rytwiany & 0.44 & 3.19 & 63.68 \\
Sitkówka-Nowiny & 0.33 & 72.72 & 489.18 \\
Solec-Zdrój & 1.47 & 6.11 & 102.02 \\
Staszów - rural area & 0.12 & 6.17 & 109.81 \\
Stąporków - rural area & 0.05 & 0.14 & 2.38 \\
Stopnica & 0.16 & 2.06 & 32.31 \\
Strawczyn & 0.52 & 0.55 & 4.85 \\
Szydłów & 0.24 & 54.19 & $1,164.11$ \\
Zawichost - rural area & 0.65 & 45.00 & 925.93 \\
Złota & 0.07 & 0.50 & 8.11 \\
\hline
\end{tabular}

Source: the author's own calculations based on data from the Local Data Bank of the Central Statistical Office of Poland.

The areas with favourable locations, close to the province's capital city and transportation routes dominated in the year in question. These are also areas situated in the centre of the Świętokrzyskie Mountains. The remaining areas had a marginal impact with regard to the measured indices in the same year. In the year 2012, 48 villages recorded their tourist accommodation facilities in the statistical data of the Central Statistical Office of Poland (Table 2).

Table 2. Indicators describing tourist phenomena in rural areas of the Świętokrzyskie Province in 2012

\begin{tabular}{|c|c|c|c|}
\hline Territorial unit & $\begin{array}{c}\text { Tourist } \\
\text { accommodation } \\
\text { density index }\end{array}$ & Defert's index & Schneider's index \\
\hline 1 & 2 & 3 & 4 \\
\hline Bałtów & 0.47 & 14.92 & 422.26 \\
\hline Bieliny & 0.11 & 1.50 & 13.03 \\
\hline Bodzechów & 1.30 & 33.55 & 300.16 \\
\hline Bodzentyn - rural area & 1.41 & 40.68 & 653.66 \\
\hline Brody & 0.30 & 7.32 & 105.68 \\
\hline Busko-Zdrój - rural area & 0.58 & 5.61 & 78.31 \\
\hline Chęciny - rural area & 0.27 & 11.59 & 122.57 \\
\hline Chmielnik - rural area & 0.16 & 0.09 & 1.57 \\
\hline Daleszyce & 0.79 & 16.42 & 268.39 \\
\hline Dwikozy & 0.52 & 32.16 & 302.00 \\
\hline Fałków & 0.30 & 2.45 & 68.49 \\
\hline Gowarczów & 0.20 & 7.17 & 152.49 \\
\hline Górno & 5.92 & 281.58 & $1,704.67$ \\
\hline Iwaniska & 0.0 & 0.28 & 4.18 \\
\hline Końskie - rural area & 4.14 & 101.96 & $1,460.46$ \\
\hline Krasocin & 0.11 & 0.20 & 3.52 \\
\hline Kunów & 0.26 & 1.93 & 29.70 \\
\hline Łagów & 0.67 & 7.97 & 128.38 \\
\hline Łopuszno & 0.18 & 3.64 & 71.04 \\
\hline Małogoszcz - rural area * & 1.47 & 31.37 & 546.01 \\
\hline Masłów & 6.33 & 249.91 & $2,053.11$ \\
\hline Michałów & 0.12 & 0.21 & 4.80 \\
\hline
\end{tabular}




\begin{tabular}{|c|c|c|c|}
\hline 1 & 2 & 3 & 4 \\
\hline Miedziana Góra & 4.44 & 53.97 & 349.99 \\
\hline Mniów & 0.00 & 0.67 & 6.82 \\
\hline Morawica & 0.19 & 20.26 & 187.45 \\
\hline Moskorzew & 0.37 & 9.89 & 262.83 \\
\hline Nagłowice & 0.79 & 16.38 & 370.38 \\
\hline Nowa Słupia & 3.09 & 64.88 & 574.78 \\
\hline Obrazów & 0.38 & 3.58 & 39.07 \\
\hline Opatowiec & 0.35 & 37.99 & 755.33 \\
\hline Piekoszów & 0.12 & 0.50 & 3.16 \\
\hline Pierzchnica & 0.10 & 0.63 & 13.65 \\
\hline Pińczów - rural area & 0.40 & 8.50 & 166.21 \\
\hline Raków & 2.86 & 2.27 & 74.69 \\
\hline Ruda Maleniecka & 0.41 & 10.95 & 368.42 \\
\hline Rytwiany & 0.31 & 10.80 & 209.37 \\
\hline Sadowie & 0.00 & 6.66 & 131.41 \\
\hline Sędziszów & 0.70 & 1.93 & 42.85 \\
\hline Sitkówka-Nowiny & 2.30 & 111.61 & 681.72 \\
\hline Solec-Zdrój & 5.86 & 152.06 & $2,528.86$ \\
\hline Stąporków - rural area & 0.14 & 1.75 & 32.40 \\
\hline Stopnica* & 0.44 & 21.20 & 338.92 \\
\hline Strawczyn & 1.16 & 12.57 & 105.07 \\
\hline Suchedniów & 2.53 & 8.87 & 70.78 \\
\hline Szydłów & 1.57 & 50.29 & $1,131.22$ \\
\hline Włoszczowa & 0.05 & 0.03 & 0.74 \\
\hline Zagnańska & 0.47 & 7.14 & 69.14 \\
\hline Zawichost & 0.98 & 25.70 & 552.09 \\
\hline
\end{tabular}

Source: the author's own calculations based on data from the Local Data Bank of the Central Statistical Office of Poland.

In 2012, the role of communes located in suburban zones as well as those with specialised function of a health resort such as e.g. Solec-Zdrój increased. The importance of locations situated in the area of the Świętokrzyskie Mountains - Bodzentyn and Nowa Słupia - also increased. According to J. Bański, ${ }^{9}$ a favourable location usually cumulates positive trends in social and economic development, but the attractive location of a commune does not necessarily lead to its successful economic development - it has to be accompanied by additional elements facilitating socio-economic development. A positive aspect in the possible development of rural areas is the state of the tourist development of areas famous for their unique natural attractions (the Świętokrzyskie Mountains) and the improvement of accommodation in areas with health resort establishments.

The next stage of analysis has focused on the structure of the synthetic measure of the tourist function. It is composed of three elements: tourist values, tourist development and tourist movement. Each module has 2 variables (Table 3 ).

${ }^{9}$ J. Bański, Uwarunkowania sukcesu gospodarczego na wsi, in: Dychotomiczny rozwój obszarów wiejskich? Czynniki progresji, czynniki peryferyzacji, ed. W. Kamińska, K. Heffner, „Studia KPZK” 2011, t. CXXXIII, Warszawa, p. 62 . 
Table 3. Measures of the tourist function development

\begin{tabular}{lll}
\hline \multicolumn{1}{c}{ Measures } & & \multicolumn{1}{c}{ Items } \\
\hline Measures of environmental & 1 & \% of protected areas in the total area of a gmina \\
benefits & 2 & number of structures registered as historic monuments in a gmina against its area \\
\hline Measures of tourist & 3 & number of bed places per 1,000 inhabitants \\
development & 4 & $\%$ of persons employed in section I (activity connected with accommodation and food services) \\
\hline Measures of tourist & 5 & number of bed places users per 1,000 inhabitants \\
movement & 6 & number of bed places used per 1,000 inhabitants \\
\hline
\end{tabular}

Source: own calculations based on www.stat.gov.pl, www.zabkielce.prot.pl, Baran, Noga, Kiniorska 2015.

In 2013 the measure of the tourist functions development in rural areas of the Świętokrzyskie Province were between -0.58 in the Łączna commune up to 5.11 in the Solec-Zdrój commune. According to the above mentioned measure, 5 types of communes were defined in the rural areas of the Świętokrzyskie Province (Table 4). The biggest group was composed of communes with the very poorly developed tourist function. This group encompassed 50 communes which in 2013 had $48.3 \%$ of rural areas inhabitants in the Świętokrzyskie Province. Majority of these communes were concentrated along the western border of the Świętokrzyskie Province with the peripheral location as regards both the biggest cities of the region and smaller county towns.

Table 4. Synthetic measure of the tourist function development in the rural areas of the Świętokrzyskie Province in 2013

\begin{tabular}{lcccc}
\hline \multirow{2}{*}{ Synthetic measure } & \multicolumn{2}{c}{ Number of } & \multicolumn{2}{c}{ Percentage } \\
\cline { 2 - 5 } & gminas & people & gminas & people \\
\hline Very high (1.95 and more) & 2 & 15,561 & 2.1 & 2.2 \\
High (1.23-1.94) & 4 & 45,365 & 4.1 & 6.4 \\
Medium (0.51-1.24) & 7 & 48,410 & 7.2 & 6.9 \\
Low (-0.21-0.51) & 34 & 253,242 & 35.0 & 36.2 \\
Very low (below -0.21) & 50 & 337,867 & 51.6 & 48.3 \\
\hline In total & 97 & 700,445 & 100.0 & 100.0 \\
\hline
\end{tabular}

Source: author's own calculations based on data from the Central Statistical Office of Poland (www.stat.gov.pl), Baran, Noga, Kiniorska 2015.

The subsequent, 2013 group, was composed of the communes with the low level tourist functions, where synthetic measure was in the range of -0.21 to 0.51 ; it encompassed 34 units with $36.2 \%$ of rural areas inhabitants of the Świętokrzyskie Province. They were located mostly in the eastern part of the province. The medium level of tourist function was the feature of the units located in the northern part of the Kielce county. The group with the high and very high level of tourist functions included six communes (Szydłów, Chęciny, Górno, Końskie, Masłów, and Solec-Zdrój). These units were characterised by a high number of people using bed places per 1,000 inhabitants and a high number of registered historic monuments in a commune against its area. Apart from the areas located in the Świętokrzyskie Mountains, the areas with the health 
resort functions such as e.g. Solec-Zdrój commune become more important. This commune has the largest and one of the strongest sources of sulphide water in Europe, a fact of great advantage which had stimulated both the construction of mineral swimming pools and the emergence of sulphide springs. With the increasing clients' and patients' interest, inhabitants of this area decided to meet the visitors' expectations and started individual businesses to provide them with the proper accommodation and food services (guest houses, agritourism). ${ }^{10}$

It can be assumed that the fastest development of tourism will be visible in those rural areas that will properly advertise their tourist attractions - both their natural environment and human heritage. They are also investing in the tourist facilities development. An active support from local authorities and community is of high importance here. According to the holistic tourism model, the tourist management should follow the principles of a sustainable development. The role of local authorities is developing local tourism, while simultaneously protecting natural environment and local resources. Privately-owned tourist businesses, hotels, guest houses, accommodation in private houses as well as agritourism farms stimulate management of tourism in the communes. ${ }^{11}$

\section{Conclusions}

For many centuries rural areas were associated with agriculture, still the element shaping most rural areas and one which has long remained the basic part of the rural areas economy. However, the deagrarisation of social and economic structures of rural areas is becoming more and more visible; non-agricultural functions, including tourism, are becoming elements of the rural space. ${ }^{12}$ The development of the tourist function determines numerous factors including e.g. the benefits that rural areas derive as well as their accommodation, food and recreational base potentials. In rural areas various forms of tourism may be organised within locations with excellent natural environmental resources or outstanding cultural attractions. It mainly refers to villages located in the suburban zones, near rivers, lakes or areas with landscape attractions. ${ }^{13}$

The study shows a certain interdependency existing between the development of tourism and socio-economic conditions. This relation is mostly visible in the areas peripheral to the capital city of the province or the rural areas with more specialised non-agricultural functions, including the industrial function (Sitkówka-Nowiny, Końskie). It may be assumed that the development of tourism in rural areas can may be limited due to larger difficulties in finding external investors. Therefore, tourism can be based on internal resources of communes or their inhabitants. In the

${ }^{10}$ E. Baran, M. Noga, I. Kiniorska, Rozwój funkcji turystycznej obszarów wiejskich województwa świętokrzyskiego, „Studia KPZK” 2015, t. CLXIII, p. 264.

${ }^{11}$ A. Kotala, A. Niedziółka, Rola $i$ znaczenie władz lokalnych $w$ rozwoju agroturystyki $w$ woj. małopolskim, in: Ekonomiczne i spoleczne aspekty rozwoju turystyki wiejskiej, ed. I. Sikorska-Wolak, SGGW, Wydział Nauk Ekonomicznych, Warszawa 2008, p. 281.

12 J. Poczta, Renta położenia jako warunek powodzenia działalności agroturystycznej oraz kształtowania produktów turystycznych na obszarach wiejskich, in: Podaż turystyczna jako determinanta kształtowania popytu turystycznego, Zeszyty Naukowe Uniwersytetu Szczecińskiego nr 701, „Ekonomiczne Problemy Usług” nr 86, Szczecin 2012 , p. 301.

${ }^{13}$ B. Górz, Funkcje turystyki na obszarach wiejskich, in: Studia nad turystyką. Tradycje, stan obecny i perspektywy badawcze, Instytut Geografii i Gospodarki Przestrzennej, Uniwersytet Jagielloński, 2007, p. 229. 
areas more distant from urban centres, with traditional agriculture and more difficult conditions for development, underinvestment is a key factor. Such areas have often the unused environmental and recreational potential, unanalysed in the study but important for defining the possible development of the Świętokrzyskie Province. The highest development potential is the feature of the suburban units located in the vicinity of Kielce and subregional centres. Apart from the peripheral location, other development barriers include the access to transportation system and conflicts between environmental protection (63\% of the province's area with special natural values) and other forms of spatial development.

\section{References}

Bański J., Uwarunkowania sukcesu gospodarczego na wsi, in: Dychotomiczny rozwój obszarów wiejskich? Czynniki progresji, czynniki peryferyzacji, ed. W. Kamińska, K. Heffner K, „Studia KPZK” 2011, t. CXXXIII: 61-76.

Baran E., Noga M., Kiniorska I., Rozwój funkcji turystycznej obszarów wiejskich województwa świętokrzyskiego, „Studia KPZK" 2015, t. CLXIII: 252-266.

Chudy-Hyski D., Ocena wybranych uwarunkowań rozwoju funkcji turystycznej obszaru, „Infrastruktura i Ekologia Terenów Wiejskich", nr 2/1 PAN, Kraków 2006.

Durydiwka M., Kształtowanie się funkcji turystycznej na obszarach wiejskich w Polsce, in: Studia nad turystyka. Tradycje, stan obecny i perspektywy badawcze. Geograficzne, społeczne i ekonomiczne aspekty turystyki, Instytut Geografii i Gospodarki Przestrzennej, Uniwersytet Jagielloński, 2007: 261- 269.

Durydiwka M., Czynniki rozwoju i zróżnicowanie funkcji turystycznej na obszarach wiejskich $w$ Polsce, Wydział Geografii i Studiów Regionalnych, Uniwersytet Warszawski, Warszawa 2012.

Faracik R., Turystyka w strefie podmiejskiej Krakowa, Uniwersytet Jagielloński, Kraków 2006.

Górz B., Funkcje turystyki na obszarach wiejskich, in: Studia nad turystyka. Tradycje, stan obecny i perspektywy badawcze. „Geograficzne, społeczne i ekonomiczne aspekty turystyki”, Instytut Geografii i Gospodarki Przestrzennej, Uniwersytet Jagielloński 2007: 223-235.

Heffner K., Kierunki zmian w przestrzeni wiejskiej Polski-wpisywanie sięw przestrzeń wsi europejskiej, „Studia KPZK” 2014, t CLVI: 33-56

Jackowski A., Typologia funkcjonalna miejscowości turystycznych (na przykładzie województwa nowosądeckiego), Uniwersytet Jagielloński, Kraków 1981.

Janowski I., Agroturystyka i ekoturystyka - szansa odmiany oblicza świętokrzyskiej wsi, in: Wybrane problemy rozwoju regionalnego, ed. W. Kamińska, Prace IG AŚ in Kielce 2004.

Kamińska W., Pałka-Łebek E., Miejsce turystyki w rozwoju obszarów wiejskich. Przykład województwa świętokrzyskiego, in: Współczesne procesy urbanizacji obszarów wiejskich, eds. W. Kamińska, M. Mularczyk, IG Uniwersytet Humanistyczno-Przyrodniczy Jana Kochanowskiego, Kielce 2009.

Kamińska W., Piwońska E., Conditioning for Agritourism Development in Poland. Świętokrzyskie Voivodeship Case, Geology, Geoecology and Evolutionary Geography, No. 9, Herzen State University of Russia, St. Petersburg 2009.

Kamińska W., Mularczyk M., Development of Agritourism in Świętokrzyskie Voivodeship, Significance of Social Capital, “Geology, Geoecology and Evolutionary Geography” 2010, No. 10.

Kiniorska I., Wrońska-Kiczor J., Turystyka na wsi świętokrzyskiej, in: Turystyka szansą rozwoju obszarów wiejskich, eds. I. Kiniorska, E. Pałka, IG Uniwersytet Humanistyczno-Przyrodniczy Jana Kochanowskiego w Kielcach, PTG 2010.

Kiniorska I., Potencjal rozwojowy obszarów wiejskich województwa świętokrzyskiego a polityka spójności, „Studia KPZK” 2014, t. CLVI: 360.

Kłodziński M., Główne funkcje polskich obszarów wiejskich z uwzględnieniem dezagraryzacji wsi $i$ pozarolniczej działalności gospodarczej, „Studia BAS” 2010, nr 4 (24).

Kotala A., Niedziółka A., Rola i znaczenie władz lokalnych w rozwoju agroturystyki w woj. małopolskim, in: Ekonomiczne i społeczne aspekty rozwoju turystyki wiejskiej, ed. I. Sikorska-Wolak, SGGW Wydział Nauk Ekonomicznych, Warszawa 2008: 279-292. 
Krzyżanowska K., Innowacyjność w turystyce wiejskiej - teoria i praktyka, in: Innowacje $w$ rozwoju turystyki, eds. K. Nuszkiewicz, M. Roman, Wydawnictwo Zespołu Szkół Centrum Kształcenia Rolniczego im. Jadwigi Dziubińskiej w Golądkowie 2013.

Majewska I., Kierunki rozwoju turystyki na obszarach wiejskich w nowej perspektywie finansowej Unii Europejskiej, in: Turystyka wiejska bez granic, ed. C. Jastrzębski, Wyższa Szkoła Ekonomii, Prawa i Nauk Medycznych w Kielcach 2015: 39-48.

Miszczuk A., Kapitał ludzki i społeczny w procesie rozwoju obszarów wiejskich woj. lubelskiego, in: Kapitał ludzki i społeczny w procesie rozwoju obszarów wiejskich, ed. W. Kamińska, K. Heffner, „Studia KPZK” 2010, t. CXXVI: 144-160.

Nita J., Kamieniołomy w krajobrazie i geoturystyce, in: Krajobraz a turystyka, Prace Komisji Krajobrazu Kulturowego PTG nr 14, Sosnowiec 2010: 243-251.

Pałka E., Diagnoza bazy agroturystycznej w województwie świętokrzyskim $w$ aspekcie procesów integracyjnych, „Infrastruktura i Ekologia Terenów Wiejskich”, PAN Oddział w Krakowie, 2007, nr 1.

Parzonko A.J., Rola doradztwa w upowszechnianiu rozwiązań innowacyjnych $w$ turystyce wiejskiej, in: Innowacje w rozwoju turystyki, eds. K. Nuszkiewicz, M. Roman, Wydawnictwo Zespołu Szkół Centrum Kształcenia Rolniczego im. Jadwigi Dziubińskiej w Golądkowie 2013.

Puciato D., Woś B., Innowacji jako forma wzbogacania oferty wybranych gospodarstw agroturystycznych w Górach Świętokrzyskich, „Folia Pomeranae Universitatis Technologiae Stietinensis. Oeconomica” 2011, t. 288 , nr 64.

Poczta J., Renta położenia jako warunek powodzenia działalności agroturystycznej oraz kształtowania produktów turystycznych na obszarach wiejskich, in: Podaż turystyczna jako determinanta ksztaltowania popytu turystycznego, Zeszyty Naukowe Uniwersytetu Szczecińskiego nr 701, „Ekonomiczne Problemy Usług” nr 86, Uniwersytet Szczeciński 2012.

Rosner A., Zróżnicowanie zaludnienia obszarów wiejskich w Polsce. Obszary zmniejszające zaludnienie i koncentrujące ludność, in: Dychotomiczny rozwój obszarów wiejskich? Czynniki progresji, czynniki peryferyzacji, eds. W. Kamińska, K. Heffner, „Studia KPZK” 2011, t. CXXXIII: 125-139.

Szwichtenberg A., Gospodarka turystyczna polskiego wybrzeża, Wydawnictwo Uczelniane Politechniki Koszalińskiej, Koszalin 2006.

Szromek A.R, Przegląd wskaźników funkcji turystycznej i ich zastosowanie w ocenie rozwoju turystycznego obszaru na przykładzie gmin województwa śląskiego, Zeszyty Naukowe Politechniki Śląskiej, Seria Organizacja i Zarządzanie, 2012, f. XX.

Tucki A., Regionalne aspekty rozwoju turystyki na przykładzie województwa lubelskiego, „Studia nad turystyką, Prace geograficzne i regionalne”, Instytut Geografii i Gospodarki Przestrzennej UJ, Kraków 2007.

Warszyńska J., Funkcja turystyczna Karpat Polskich, „Folia Geographica” 1985, Series Geographica-Oeconomica, t. XVIII.

Woźniak M., Nowe koncepcje w zarządzaniu agroturystyka, in: Innowacyjność w turystyce, ed. J. Krupa, Rzeszów 2010. Żek M., Funkcja turystyczna obszaru nadbużańskiego, „Turystyka i Hotelarstwo” 2008, nr 14. 


\title{
WYBRANE ASPEKTY ROZWOJU TURYSTYKI OBSZARÓW WIEJSKICH WOJEWÓDZTWA ŚWIĘTOKRZYSKIEGO
}

\author{
SŁOWA KLUCZOWE \\ potencjał demograficzny, potencjał gospodarczy, infrastruktura \\ STRESZCZENIE \\ Turystyka stanowi jeden z ważniejszych elementów rozwoju wielofunkcyjnego obsza- \\ rów wiejskich. Głównym celem opracowania była ocean wybranych uwarunkowań roz- \\ woju turystyki, ze szczególnym uwzględnieniem procesów demograficznych i gospodar- \\ czo-infrastrukturalnych. W opracowaniu wykorzystano dane statystyczne pochodzące \\ z BDL GUS, zakres czasowy przeprowadzonej analizy objął lata 2002-2012. Obszarem \\ badawczym były tereny wiejskie województwa świętokrzyskiego.
}

